\title{
Oil back on the global agenda
}

\section{A permanent decline in global oil production rate is virtually certain to begin within 20 years. Serious planning is needed to deal with the economic consequences.}

\section{Craig Bond Hatfield}

In 1985, global oil consumption was 59.7 mil-

lion barrels per day ${ }^{1}$; by

1995 it was more than 69 million barrels per day $^{2}$. This 16 per cent rise in demand was supplied almost entirely by an increase in oil production by members of the Organization of Petroleum Exporting Countries (OPEC) - mostly in the Middle East - from 16.1 to 25 million barrels per day ${ }^{1,3}$. Growth in production in the North Sea, Latin America and

IMAGE UNAVAILABLE FOR COPYRIGHT REASONS
Asia has barely exceeded precipitous declines in US and Russian oil production.

Geological data indicate that, during the next ten years, oil production outside OPEC countries will remain incapable of significant, sustained growth and is likely to begin a permanent decline during the first decade of the twenty-first century. This seems inevitable because new discoveries of reserves are not keeping pace with production. Globally, new discovery has averaged less than 9 billion barrels per year since 1985 (ref. 4), while consumption has averaged more than 23 billion barrels per year ${ }^{1}$. The rate of discovery peaked in the 1960s and has since declined ${ }^{5}$, despite record high rates of exploration in the early 1980 s.

\section{Low reserves}

Most of the reported 'growth' in oil reserves during the past decade has been from revised estimates: in 1988 and 1989, Venezuela, Iran, Iraq, Abu Dhabi and Saudi Arabia reported upwards revisions totalling 277 billion barrels ${ }^{1}$. This accounts for nearly all the growth in global reserves of oil from 1987 (700 billion barrels) to 1990 (1,000 billion barrels). Because it is improbable that these OPEC countries had valid reasons for such gargantuan and simultaneous revisions, it has been suggested $^{6}$ that the increases are political rather than real, perhaps intended to discourage exploration for oil elsewhere in the world or to help establish OPEC production quotas.

If it is the case that the world's oil reserves are indeed as great as 1,000 billion barrels, a continuation of the current oil consumption rate of 26 billion barrels per year would deplete global reserves by the year 2036. The average estimate of about 550 billion barrels of producible oil yet to be discovered ${ }^{7}$ would add another 21 years in the unlikely event that there is no growth in consumption rate.

But such calculations are unrealistic, because global oil production rate will pass its maximum and begin to decline long before resources are exhausted. For example, oil production in the United States reached its peak in 1970 and has declined since, as was clearly predicted in 1956 (ref. 8). This forecast was the first to apply to oil production a mathematical model that yields growth in production rate until about half of the producible resource has been consumed, after which the production rate declines until the resource is exhausted. It is possible that new oil-recovery technology, as used in the North Sea, could extend growth in production rate beyond the point at which half of the producible resource has been consumed, but in this event the subsequent decline in rate would be accelerated.

\section{How long can growth continue?}

For how long can the global oil-production rate continue to grow? Even if the reported reserves were accurate, the addition of the average estimate of about 550 billion barrels of producible oil yet to be discovered would yield 1,550 billion barrels of oil remaining to be produced. Taken together with the approximately 800 billion barrels already consumed, this gives 2,350 billion barrels of 'ultimate' production, which is greater than several recent estimates of ultimate oil production $^{6,7}$. The mid-point, at which half of the ultimate production will have been consumed, would be the year 2011, if production rate remains at its present level.

But if, as is likely, some of the reported reserves do not exist, or if, as discovery rates of recent years suggest, we have less than 550 billion barrels of producible oil yet to discover, or if consumption continues to grow, cumulative production will reach half of the ultimate production in the first few years of the twenty-first century. In this case, global oil-production rate will peak and begin its decline during the first or second decade of the twenty-first century.

If global demand for oil grows from 1995 to 2005 by 16 per cent, as it did from 1985 to 1995, demand for OPEC oil by the year 2005 will be 36 million barrels a day. OPEC currently produces 25 million barrels a day and has an estimated production capacity of about 29 million barrels a day, excluding Iraqi production. (Iraq's maximum produc- tion rate over a year is 3 million barrels a day.) So OPEC must increase its production capacity significantly if it is to meet even conservative projections of demand by 2005 . What will maximum potential production capacity be between 2010 and 2015, when OPEC will be near (just approaching or just beyond) the mid-point of its ultimate production?

The world probably will reach its maximum oil production rate in the next 15 years. Growth in global oil-consumption rate during 1996 was considerably greater than its average annual growth for the past ten years. Such increases are mainly driven by growing demand in countries where economic growth is accelerating: since 1985, energy use has grown approximately 30 per cent in Latin America, 40 per cent in Africa and 50 per cent in Asia ${ }^{1}$.

Energy consumption in developing countries could surpass that in economically developed countries within 20 years. There will be growing competition for a dwindling oil supply, which raises the question of how long standards of living can rise in the developing world and how long they can be maintained in the developed world.

Despite the intensive, intergovernmental debates on the environmental effects of energy policies, geological constraints on the amount of inexpensive fluid fuel that can be produced will soon override governments' decisions about future rates of fossil-fuel burning. The past century of unprecedented economic growth has been based largely on increasing availability of cheap but rapidly dwindling petroleum resources. It is unfashionable in energy policies and economic theory to recognize a time limit on growth in oil consumption rate. But the arithmetic on which my argument is based must be acknowledged. The coming era of permanent decline in oil-production rate and the economic and social implications of this phenomenon demand serious planning by the world's governments.

Craig Bond Hatfield is in the Department of Geology, University of Toledo, Toledo, Ohio 43606, USA.

. Basic Petroleum Data Book: Petroleum Industry Statistics Vol. XVII, No. 1 (American Petroleum Institute, Washington DC, 1997).

2. World Oil 216, 17 (December 1995).

3. Knapp, D. H. Oil Gas J. 93, 35-43 (25 December 1995).

4. Laherrere, J. World Oil 215, 33 (January 1994).

5. Ivanhoe, L. F. World Oil 216, 77-88 (October 1995).

6. Campbell, C. J. The Golden Century of Oil 1950-2050 (Kluwer, Dordrecht, 1991).

7. Masters, C. D., Root, D. H. \& Attanasi, E. D. Science 253, 146-152 (1991).

8. Hubbert, M. K. in Drilling and Production Practice, 7-25 (American Petroleum Institute, Washington DC, 1956). 